\title{
Jonathan Edwards (1703-1758) and the Nature of Theology
}

\author{
Adriaan C. Neele ${ }^{1}$ \\ Jonathan Edwards Centre Africa \\ University of the Free State, Bloemfontein, South Africa
}

\begin{abstract}
This article proposes that Jonathan Edwards' inquiry into the nature of theology continues the tradition of Protestant scholasticism, and appropriated medieval and early Protestant models of the systems of theology within the theological context of eighteenth-century New England. In fact, Edwards's use of post-Reformation reformed scholasticism was a mediating source of medieval theology of Franciscan and Scotist origin. E Brooks Holifield in Theology in America (2003) has the following to say:
\end{abstract}

Edwards drew the common distinction between the two kinds of theological knowledge, the first speculative ... and the second practical ... The aim of [Edwards's] theology was to nurture a "sense" of divine things that took one deeper into their nature than the speculative understanding alone could penetrate and to "guide" and influence us in our practice (Holifield 2003:102).

Although Holifield asserts that Edwards' aim and distinction of theology may have been indebted to the Reformed scholar, Petrus van Mastricht (1630-1706), many academics that focus on the theology of Edwards, such as Ridderbos (1907), Cherry (1966), Gerstner (1996), Holmes (2000) and Lee (2000), have overlooked such indebtedness, which may be an underlying or overarching theme in the interpretation of the nature of Edwards' theology. One reason for this oversight is that many of Edwards' sources remain in (untranslated) Latin, as Amy Plantinga Pauw (2002:27) points out, following Norman Fiering. Another reason may be that, as Gerry McDermott recently remarked, "more scholarly work needs to compare him [Edwards] with European thinkers and issues, and thereby include him in the ongoing discussions of international philosophy and theology". 2

This article therefore attempts to evaluate Edwards' theological inquiry by means of a deeper view of Protestant scholasticism and its trajectories. I focus on a single document in which Edwards, typically, lays out his understanding of the nature of theology - a sermon delivered in November 1739, and published as "The importance and advantage of a thorough knowledge of divine truth" (1788).

The period 1737 to 1742 was a challenging and changing time in New England's history. War (FrenchIndian raids, the War of Jenkins' Ear) and awakenings shaped America's early history and theology in unprecedented ways, in particular following the Great Awakening, and event that is fixed to that towering figure in intellectual history, Jonathan Edwards (1703-58), preacher, theologian, philosopher, missionary, pastor and university president. ${ }^{3}$

Although steeped in seventeenth-century English puritanism and continental post-Reformation reformed thought, New England's theological orthodoxy and practice were put to the test during these years. The rise of Arminianism, the dissemination of Deism, and the news about the "New Methodists" (Edwards 2003 22:108), such as John Wesley (1703-91) and George Whitefield (1714-70), all contributed to division and reconstituted allegiances in the British colony. The concern over Arminianism was expressed in an exchange of letters in March 1739 between Captain Benjamin Wright and the Reverend Benjamin Doolittle of Northfield, Massachusetts. Doolittle accused his parishioner Wright of having "[s]ignified nothing of a desire of peace and love", while Wright charged that his pastor had "often advanced Arminian principles both in pulpit and private conversation" (Edwards 2008, 32: C55, C57). The danger of Deism was not only generally known in New England, but the congregation of Northampton in particular was, thanks to their pastor, well versed in it. In sermon twenty-four of the History of the work of redemption series of mid-1739, Edwards (1989 9:432) warned:

\footnotetext{
Adriaan C Neele, Yale University Divinity School, Associate Editor and Director Jonathan Edwards Center, Professor Extraordinary and Research Associate, University of the Free State, PO Box 339, Bloemfontein, 9300, South Africa (UFS).

E-mail: adriaan.neele@yale.edu.

Jonathan Edwards Society <http://www.jesociety.org/2010/02/08/whither-edwards-studies/\#ixzz10k4bQEUt > (Sept. $27,2010$.

See e.g. Marsden G 2003. Jonathan Edwards: A Life. New Haven, London: Yale University Press; Morris WS 1955. The Young Jonathan Edwards: A Reconstruction. Chicago: PhD thesis, University of Chicago; 2005. The Jonathan Edwards Classic Studies Series, Eugene, OR: Wimf and Stock.
} 
Again, another thing that has of late exceedingly prevailed among Protestants, and especially in England, is deism. The deists wholly cast off the Christian religion, and are professed infidels. They ben't like the heretics, Arians and Socinians, and others ... They deny any revealed religion ... and say that God has given mankind no other light to walk by but his own reason.

Edwards was not an insignificant participant in these transformative years of New England, although based in the rural town of Northampton. His Faithful narrative of the surprising work of God, published in London (December 1737) and Boston (December 1738), had placed him in the emerging network of the transatlantic evangelical community (O'Brien 1994:38-57), and his preaching of various discourses, such as on the parable of the wise and foolish virgins (January-April 1738), the series on 1 Corinthians 13 (April-October 1738) later published as Charity and its fruits, and the sermons that became known as A history of the work of redemption (March-August 1739), established him as an extraordinary preacher.

However, it is precisely in these taxing years for New England's theology that Edwards evolved as a theologian par excellence: historically informed and contemporarily relevant. It is important to note that the pastor of Northampton did not publish a systematic theology like the post-Reformation reformed theologians François Turretin (1623-87), (Turretin 1680-86) and Mastricht (1630-1706) (Mastricht 1699), or like his eighteenth-century protégées Joseph Bellamy (1719-90) (Bellamy 1750) and Samuel Hopkins (1721-1803) (Hopkins 1793). Edwards commented on his predecessors, whose works are leading examples of seventeenthcentury Protestant scholasticism joined with piety, as follows:

They are both excellent. Turretin is on polemical divinity; on the Five Points, and all other controversial points; and is much larger in these than Mastricht; and is better for one that desires only to be thoroughly versed in controversies. But take Mastricht for divinity in general, doctrine, practice, and controversy; or as an universal system of divinity and it is much better than Turretin or any other book in the world, excepting the Bible, in my opinion (Edwards 1998 16:217).

Edwards' generous praise was an echo of earlier praise, commencing with Cotton Mather's handbook for students studying for the ministry, the Manuductio ad Ministerium:

But after all there is nothing that I can with so much Plerophorie Recommend unto you, as a Mastricht, his Theologia Theoretico-practica. That a Minister of the Gospel may be Thoroughly furnished unto every Good Work, and in one or two Quarto Volumns enjoy a well furnished Library, I know not that the Sun has ever shone upon an Humane Composure that is equal to it (Mather 1726:88).

In fact, Mastricht's work was highly valued by such well-known New England theologians as Benjamin Colman (Colman 1736:27-28), Joseph Seccombe (Seccombe 1742), Mastricht's editor and translator of "On Regeneration" (Mastricht 1770), Samuel Hopkins (Hopkins 1793:769) and Joseph Bellamy. ${ }^{4}$ Moreover, Edwards Amasa Park reported that Jonathan Edwards, Jr. read Mastricht's Theoretico-practica theologia seven times.

In spite of or thanks to Mastricht's work, however, the absence of a published form of systematic theology or, following the eighteenth-century term, "body of divinity," in the Edwards corpus does not imply that no consideration was given to such a project. On the contrary, as early as 1724 Edwards drafted an outline of a treatise, entitled $A$ rational account of the principles and main doctrines of the Christian religion. Although it seems that he abandoned this project after 1740, the thought of composing a body of divinity never left him, as he attested in a letter in 1757 to the Trustees of the College of New Jersey (Princeton University):

I have had on my mind and heart (which I long ago began, not with any view to publication) a great work, which I call A History of the Work of Redemption, a body of divinity in an entire new method, being thrown into the form of an history, considering the affair of Christian theology (Edwards 1998 16:727).

Mastricht, the favourite theologian of New England, and Edwards in particular, prefaced his Theoretica-practica theologia (1699) with similar words:

\footnotetext{
Joseph Bellamy. The Works of Joseph Bellamy, D.D. Boston, Doctrinal Tract and Book Society, 1850-1853, xiv. Jonathan Edwards lent
} a copy of Mastricht's work to Bellamy. Cf. Edwards 26:227. See Haykin 2007:85. 
I had planned for long ... a great work about the adventures of the church... [and] provide a particular sketch about the history of the church... dealing about the dispensatione foederis gratia through all the ages of the Church (Mastricht 1699:1-2).

Moreover, in the tumultuous years of 1737 to 1742, Edwards drafted at the close of 1739 a "Preface to the Rational Account", in which he mentioned, "some things that may justly make us suspect that the present fashionable divinity is wrong" (Edwards 2000 18:546-847). Finally, and precisely at that time, Edwards not only included in one of his Sermon notebooks a sketch of a homily on Hebrews 5:12, but also preached an extensive treatment of the text in November 1739 at Northampton, posthumously published as The importance and advantage of a thorough knowledge of divine truth (Edwards 2003 22:82). No manuscript has ever been located. The text was first published in Jonathan Edwards, Practical Sermons never before published (Gray 1788). What is suggested here is that in these times of New England's contested theology and its practice, Edwards emerged as a prime example of effectively communicating the fundamentals of Christian theology catholic in its trajectory and contemporary in its setting.

Therefore, a brief analysis with historical-theological commentary of this homily, both in structure and content, is required to discern Edwards' position in a transitional moment of theology.

In regard to the structure, Edwards' sermon on Hebrews 5:12 is a literary unit, most likely divided over two preaching occasions, comprising three main divisions, Text, Doctrine and Application (Edwards 1992 10:3258), of which the latter is presented as Uses and Directions. Wilson H. Kimnach convincingly argues that Edwards relied "upon the basic structure and general rationale of the seventeenth-century Puritan sermon" (Edwards 10:27). However, the form of the discourse may further have been strengthened by Edwards' profound acquaintance with Mastricht's Theoretico-practica theologia which presented each loci of Reformed theology in a fourfold and integral manner: exegesis, doctrine, elenctic and praxis - the latter also containing uses and directions (Usus primus reprehensionis ... Usus secundus adhortationis) (Mastricht 1699:4).

In particular, Mastricht's work was written not only for the study of theology but also intended for the preparation of a homily (Tandem, ut \& usum nostrorum, in homileticis pro concione habeas, id unum moneo, ut cautè observes, praedominans argumentum textus tui) (Mastricht 1699:2). In addition to the threefold division of the discourse, Edwards offers in the doctrinal section, in sketch and published form, four propositions or questions: What divinity is; what kind of knowledge in divinity is intended in the doctrine; why knowledge in divinity is necessary; and why all Christians should make a business of endeavouring to grow in this knowledge. The informed reader notices immediately Edwards' sophisticated approach to the theological discourse by raising the (medieval) scholastic quaestiones: Quid sit (what is), Qualis sit (what sort) and Quantus sit (how great). These particular rhetorical distinctions, acknowledged by Edwards as an examination "according to the rules of art", (Edwards 2003 22:85) unite Edwards' sermon structure with the method of theological inquiry of post-Reformation reformed thinkers such as Mastricht, and other Protestant scholastics (Mastricht 1699:3; Muller 2003 I:121-122) but also of medieval intellectuals such as Lombardus, Aquinas and Scotus (trû theologia sit practica) (Lombardus 1537; Aquinas 1962; Scotus 1477). In summary, the structure of Edwards' exposition on the knowledge of divinity or theology proper, then, can be characterised as the methodus theologiae and is thereby placed in a long-standing trajectory of the development of the systema of theology. This observation is further underscored by examining the content of the first question, the Quid sit, stated in Edwards' Sermon notes (Edwards 2008 36:164) as "What we mean by divinity", and in the published text, "What divinity is" (Edwards 2003 22:80-82).

Concerning the question "What is divinity?" Edwards provides, first, a general statement. "Divinity," he asserted, is "that science or doctrine which comprehends all those truths and rules which concern the great business of religion" (Edwards 2003 22:85). From a historical-theological perspective, one would recognise Edwards' ambivalence at this point of the discourse: does he mean that divinity or theologia is scientia or doctrina? Does Edwards take a Thomistic position on the formulation of theology as primary over other sciences? Such seems the initial direction that the Northampton preacher takes when he writes:

There are various kinds of arts and sciences taught and learned in the schools, which are conversant about various objects; about the works of nature in general, as philosophy; or the visible heavens, as astronomy; or the sea, as navigation; or the earth, as geography; or the body of man, as physic and anatomy; or the soul of man, with regard to its natural powers and qualities, as logic and pneumatology; or about human government, as politics and jurisprudence. But there is one science, or one certain kind of knowledge and doctrine, which is above all the rest, as it is concerning God and the great business of religion: this is divinity (Edwards 2003 22:86).

Leaving for the moment the question of Edwards' Thomistic inclination, the homilitician of Northampton worked towards a definition of "What divinity is", concluding with a twofold notion: 
Divinity is commonly defined, the doctrine of living to God; and by some who seem to be more accurate, the doctrine of living to God by Christ (Edwards 2003 22:86).

The first given definition (for Edwards "commonly defined") stands in a trajectory reaching back to Petrus Ramus (1515-1572). Ramus defined "what" divinity or theology "is", as "Theologia est doctrina bene vivendi" (Ramus 1576:6) in De Religione Christiana, which was echoed by William Perkins (1558-1602) in A golden chain, as "The body of Scripture, is a doctrine sufficient to live well" [est doctrina bene vivendi] (Perkins 1592:3). In turn, Perkins' student William Ames (1576-1633) followed his teacher by providing a concise definition of theology in the Medulla S.S. Theologiae: "Theologia est doctrina Deo Vivendi", rendered in the English edition, as "Divinity is the doctrine of living to God" (Ames 1627:1; Ames 1642:1). Ames's work was not only extraordinarily influential in early New England theology, but also belonged to Edwards' core works of study at Yale College and thereafter (Sprunger 1972; Eusden 1997). For the second part concerning the definition, "and by some who seem to be more accurate, the doctrine of living to God by Christ", Edwards most probably relied on Mastricht. As the only seventeenth-century Protestant Reformed scholastic, Mastricht expanded Ames's definition of divinity to Theologia est doctrina Deo vivendi per Christum Mastricht 1699:12). Thus, New England's theologian and philosopher provided, and the hearers of Northampton were the recipients of, a long-understood definition of the quid sit of theology but mediated by the continental protestant scholastics of the seventeenth century reaching back another hundred years to another philosopher and theologian, Ramus. The question can be raised, why Edwards felt this definition to be of such importance. He wrote, and preached,

It comprehends all Christian doctrines as they are in Jesus, and all Christian rules directing us in living to God by Christ. There is nothing in divinity, no one doctrine, no promise, no rule, but what some way or other relates to the Christian and divine life, or our living to God by Christ. They all relate to this, in two respects, viz. as they tend to promote our living to God here in this world, in a life of faith and holiness, and also as they tend to bring us to a life of perfect holiness and happiness, in the full enjoyment of God hereafter (Edwards 2003 22:86).

Returning to Edwards' Thomistic thought, such seemed to be enforced by his third question, about the necessity of the knowledge of divinity - corresponding with Aquinas' opening inquiry in the Summa Theologica on the necessity of the nature and extent of sacred doctrine (De sacra doctrina, quilis sit, et ad quae se extandat in decem articulos divisa, articulus primo, De necessitate huius doctrinae) (Aquinas 1962:1). The perceptible Thomistic quality in Edwards' view of theology, however, is modified considering his observation that "there are two kinds of knowledge of the things of divinity, viz. speculative and practical, or in other terms, natural and spiritual" (Edwards 2003:22:87). This observation is not only of great importance to the preacher at Northampton - given the attention in the doctrine and application section of the sermon to this inquiry - but also places Edwards both in a long-standing trajectory of scholastic inquiry whether theology is a science (scientia), or wisdom (sapientia), as well as a discussion of scholastic distinctions - both present in medieval and Protestant scholastic systems of theology.

With the rise of interest in Aristotles' writings in the thirteenth century, the discussion of nature and the extent of theology was formed in part by the philosopher's classification of the forms of knowledge, science (scientia) and wisdom (sapientia) (Muller 2003 I:88-96). Franciscans, such as Alexander of Hales (ca. 11831245) and Bonaventure (1221-1274) insisted on the affective, practical and experimental character of theology excluding it from consideration as scientia in the Aristotelian sense of a rational or speculative discipline (Hales 1622 I.1:3; Bonaventure 1882:1). Aquinas, on the other hand not only argues in the Summa Theologicae known to Edwards during his studies at Yale College (Catalogue 1743:39) - that "sacred doctrine is a science" (Utrum sacra doctrina sit scientia...Respondea dicendum sacram doctrinam esse scientiam (Aquinas 1962:2), but also raises the question, whether sacred doctrine is a practical science - to which Thomas, reflecting Dominican theology, replied, "it is not a practical but a speculative science" (Utrum sacra doctrina sit scientia practica ... Non ergo est scientia practica, sed magis speculative) (Aquinas 1962:3). These fairly broad lines of the character of theology find their culmination in Duns Scotus's (d.1308) formulation of theology. Scotus not only resonated with Franciscan theology, despite integrating more Aristotelian philosophy than was previously accepted, but considered theology as a discipline oriented to the ultimate goal of humanity in God: in essence praxis - that is to say, a knowledge not known for itself but directed to God (Circa prologum primi libri quaeruntur quinque. Primum est de necessitate huius doctrinae... Quartum et quintum pertinet ad genus causae finalis, et est quartum: utrum theologia sit practica; quintum: utrum ex ordine ad praxim ut ad finem dicatur per se scientia practica, Scotus n.d:1).

This medieval scholastic discussion on the character of theology - expository to matters of faith, whether theology is theoretical or practical - would re-emerge in the works of Protestant scholastic theologians, including but not limited to the Reformed theologians, and known in early eighteenth-century New England, such as Johannes Cloppenburg (1592-1652) (Cloppenburg 1684:600), Johannes Cocceius (1603-1669) 
(Cocceius 1665:65), Johannes Hoornbeek (1617-1666) (Hoornbeek 1689), and Johannes à Marck (1656-1731) (Marck 1749:13), recognising theology as a mixed discipline, both theoretico and practica, though leaning towards the practica - but rejecting its anthropological character, as proposed by the Remonstrants. However, Edwards's inquiry, whether theology is speculative or practica, was raised, in particular, in the prolegomena of the theology of Mastricht and Turretin - theologians with whom Edwards was deeply acquainted. Turretin raised the question explicitly, "Is theology theoretical or practical?" inquiring not only about the understanding the essence of theology but also on account of controversies 'of this time', such as the Remonstrants and Socinians" (An Theologia sit theoretica, an practica? Theologiae naturam; sed etiam propter Controversias huius temporis, maximè contra Socin. \& Remonstrantes, qui Theologiam ita strictè practicam dicunt, ut nihil in ea praecisè ad salutem necessarium sit, nisi quod pertinet ad praecepta morum \& promissione, Turretin 1680:22) - a concern Mastricht shared (nec Practica tantum, quae veritatis cognitionem, susque deque habeat quam Sociniani vellent \& Arminiani, quo commodius fidem in Christum, aliaque Religionis fundamentalia, negligant \& eliminent, Mastricht 1699:6).

Turretin asserted, furthermore, that a theoretical or speculative system is occupied in contemplation alone with knowledge as its object; contrary to a practical theology, which has operation for its object (Disciplina theoretica dicitur, quae in sola contemplatione occupatur, \& finem alium non habet à cognitione; Practica, quae non subsistit in solâ rei noritiâ, sed naturâ suâ \& per se tendit ad praxim, \& pro fine habet operationem, Turretin 1680:22). Therefore, the Genevan theologian concludes: theology is neither theoretical nor practical but a mixed discipline, and yet more practical than speculative, which appears, Turretin explained, "from its ultimate goal, which is praxis ... indeed nothing in theology is theoretical to such as degree and so remote from praxis that it does not bring about the admiration and worship of God; nor is a theory salvific unless it is referred to praxis" (Theologiam tamen magis esse practicam quàm speculativam patet ex fine ultimo qui est praxis, Turretin 1680:26; Muller 2003 I:353-354). In addition to Turretin's question, whether theology is speculative or practical, Edwards' most favourite theologian, Mastricht, also discussed whether the discipline is theoreticopractica (Tertio sitne habitus theoreticus? an practicus? an theoretico-practicus? Mastricht 1699:15). Although he did not reject the Thomistic position altogether, Mastricht is inclined to follow a modified Scotist position on the issue, proposing that the praxis is defined as doctrina, known for the sake of the end toward which it directs the knower. In other words, Mastricht aims to maintain a balance between the speculative and practica, expressed in the conjunction theoretico-practica, yet oriented to the practical (Quin \& negamus, esse Theoretico-practicam, proprie \& in se; quamvis, ex modo tractandi, ita eam insigniverimus: sed practicam

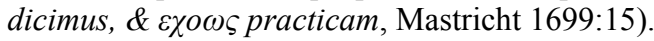

The appropriation of theological inquiry, following older scholastic models, then, is specific for postReformation theologians such as Mastricht and Turretin, while the alternative model of theology, offered by the Remonstrants or Arminians, is fundamentally different: a rejection of the recognition of theology as a mixed discipline. Simon Episcopius (1583-1643), following Jacobus Arminius (1560-1609) (Qua de causa Theologia non theoretica scientia seu doctrina est, sed practica, actionem postulans totius hominis, secundum omnes \& singulas partes eius, eamque praestantissimam, excellentiae obiecti respondentem quantum fert captus humanus, Arminius (1629:339) had argued "there is nothing in the whole of theology that is not directed toward action" (De theologia: eam non esse speculativam scientiam, sed practicam, Episcopius (1650:4). In other words, theology is not speculative but a fundamental anthropocentric drive to praxis, which was a departure from the theocentric character of Reformed theology - a prevailing concern for Edwards as well.

Although Edwards' inquiry into the nature of theology, then, stands in continuity with the Protestant and medieval scholastic inquiry, along with attention to scholastic distinctions such as speculative and practical, the quest remains, as Edwards phrased it, for, "what kind of knowledge in divinity is intended" (Edwards 2003 22:86). In the sermon on Christian knowledge he begins to point out to the hearers at Northampton that the difference between "having a right speculative notion of the doctrines contained in the Word of God, and having a due sense of them in the heart", does not imply that neither of these is intended to be exclusive of the other. But, he declared, "[I]t is intended that we should seek the former [speculative] in order to the latter [practical]. This is for Edwards of the greatest importance for, as he reminded his hearers, "[A] speculative knowledge of [the Word of God], without a spiritual knowledge, is in vain and to no purpose ... Yet a speculative knowledge is also of infinite importance in this respect, that without it we can have no spiritual or practical knowledge" (Edwards 2003 22:87). We may infer from this that Edwards did not reject the speculative entirely, as he assigned significant importance to it ("seek", he counsels, "a good rational knowledge of things of divinity"). Yet seeking the speculative comes not at the expense, but in support, of spiritual knowledge or practice.

In summary, we note the reception of older Protestant scholastic models by Edwards. Not only is a similar inquiry on the nature of theology employed by the preacher at Northampton and post-Reformation reformed theologians, but also a discerning on Edwards part of the character of theology, following Mastricht more than Turretin, as theoretico-practica theology. With that, Edwards positioned himself, on the one hand, in continuity with classical theology - rooted in post-Reformation reformed and Franciscan-Scotist traditions and, on the other hand, against its challengers, the Arminians and Deists. His familiarity with Episcopius, identified 
by Edwards as one of "the greatest Arminians", (Edwards 1957 1:289) and Deists such as Thomas Chubb (1679-1747), whose writings Edwards refutes later in particular (Edwards 1957 1:68), strengthens Edwards' point in defining the essence of theology in these transformative years of New England's history and theology.

However, the appropriation of former models of catholic and classic theology by Edwards provides a rather contemporised problem and prospect. In regard to the latter, Edwards assessed and equated the Deism of his time with the tendencies of Socinianism of previous centuries. Thus, he not only provided his vast knowledge of the post-Reformation systema as an approach for assessing contemporary challenges and proposed changes, but these systema also presented him with precise and nuanced definitions of the discipline indispensable for the interpretation of events and the formulation of his own views. Although Edwards carefully argued "the importance and advantage of a thorough knowledge of divinity" to his congregation in 1739, his argument continues to pose a challenge to the modern reader as well. The discourse is in a language other than Latin - the language of the post-Reformation and medieval sources. The continuity of the intellectual trajectory of theological language, definitions and distinctions, from the medieval period to Edwards' study at Northampton, became instantly absent in translation for the great majority of his listeners. Not that his hearers in the pew would be aware of such, or that Edwards' message was deficient by it. However, the significance of Edwards as theologian in these transformative years of New England may be lost as well - at least to most Edwards scholars. Therefore, the proposed understanding of this homily must be placed as fundamental to our understanding of Edwards' theology and his much later published and major works against Arminianism and Deism, such as Freedom of the will and Original sin - as his "Controversies" notebook dating from the 1730s attests (Edwards 2008 27:1-50).

In conclusion, in the midst of the challenging and changing years of 1737 to 1742 in New England's religious history Edwards revisited fundamental questions of theological prolegomena. The formulation of his answers demonstrated not only continuity and discontinuity but also a demanding appropriation of intellectual thought, that of the catholicity and classicality of theology. The discourse was drafted and heard in Northampton, published in 1788, and soon afterwards forgotten, yet its message was timeless: "Practice according to what knowledge you have. This will be the way to know more."

\section{Works consulted}

A Catalogue of the Library of Yale-College in New Haven. London: T. Green, 1743.

Ames, W. Medulla S.S. Theologiae. Amsterdam, 1627.

Ames, W. Marrow of Sacred Divinity. Amsterdam, 1642.

Arminius, J. Opera theologica, Disputationes, magnam partem s. theologiae complectentes, publicae \& privatae, quarum index epist. dedicatoriam sequitur. Leiden: Godefridum Basson, 1629.

Aquinas, T. 1962. Summa Theologicae. Rome: Editiones Paulinae.

Bellamy, J. True religion delineated or, Experimental religion, as distinguished from formality on the one hand, and enthusiasm on the other, set in a scriptural and rational light. In two discourses. In which some of the principal errors both of the Arminian and Antinomians are confuted ... With a preface by the Rev. Mr. Edwards. Boston: S. Kneeland, in Queen-Street, 1750.

Bonaventure. Commentaria in quator libros Sententiariam. Quaracchi Edition, 1882.

Brooks, Holifield E. 2003. Theology in America. Christian thought from the age of the Puritans to the Civil War. New Haven, London: Yale University Press.

Cherry, C. 1966. The theology of Jonathan Edwards. A reappraisal. Bloomington: Indiana University Press.

Cloppenburg, J. Theologica opera omnia Tomus prior. Amsterdam: Gerardus Borstius, 1684.

Cocceius, J. Summa theologiae ex scripturis repetita. Editio secunda. Geneva: Sumptibus Samuelis Chouët, 1665.

Colman, B. A Dissertation on the Image of God wherein Man was created. Boston: S. Kneeland \& T. Green, 1736.

Duns Scotus, J. In Quartum Librum Sententiarum. Venetia: J. de Colonia, ca. 1477.

Episcopius, S. Institutiones Theologicae, privatis lectionibus Amstelodami traditae. Amsterdam: Ioannis Blaeu, 1650.

Eusden, J.D. (ed.) 1997. The marrow of theology. William Ames (1576-1633). Grand Rapids: Baker Academic.

Fiering, N. 1991. Jonathan Edwards's moral thought and its British context. Chapel Hill: University of North Carolina Press.

Gerstner, J.H. 1996. Jonathan Edwards: A Mini-Theology. Morgan, PA: Soli Deo Gloria Publications.

Hales, A. Summa universae theologiae (Cologne: Agri., 1622).

Holmes, S.R. 2000. God of grace \& God of glory. An account of the theology of Jonathan Edwards. Grand Rapids: Wm. Eerdmans Co.

Hoornbeek, J. Theologiae practicae partes duae. Utrecht: Iohannem \& Guilielmum van de Water, 1689. 
Hopkins, S. The system of doctrines, contained in Divine revelation, explained and defended. Showing their consistence and connection with each other. To which is added, A treatise on the millennium. Boston: Isaiah, Thomas and Ebenezer, T. Andrews, 1793.

Lambert, F. 1994. "Pedlar in Divinity." George Whitefield and the Transatlantic Revivals. Princeton: Princeton University Press.

Lee, S.H. 2000. The philosophical theology of Jonathan Edwards. Princeton, NJ: Princeton University Press.

Lombard, P. Magistri Sententiarum libri IV. Paris: Iohannis Roigny, 1537.

Marck, J à. Compendium theologiae Christianae didactico-elencticum. Immixtis problematibus plurimis, \& quaestionibus etiam recentioribus adauctum. Amsterdam: Adrian. Douci \& Abr. A Paddenburg, 1749.

Marsden, G. 2003. Jonathan Edwards. A Life. New Haven, London: Yale University Press.

Mastricht, P. van. Theoretico-practica theologia. Qua, per singula capita theologica, pars exegetica, dogmatica, elenchtica \& practica, perpetua successione conjugantur. Utrecht: Thomas Appels, 1699.

Mastricht, P. van. A Treatise on Regeneration. Extracted from his System of Divinity, called Theologia theoretico-practica; and faithfully translated into English; With an Appendix containing Extracts from many celebrated Divines of the reformed Church, upon the same Subject. New Haven, [1770?].

Mather, C. Manuductio ad Ministerium. Directions for a candidate of the ministry: Wherein, first, a right foundation is laid for his future improvement; and, then, rules are offered for such a management of his academical \& preparatory studies; and thereupon, for such a conduct after his appearance in the world; as may render him a skilful and useful minister of the Gospel. Boston, 1726.

Morimoto, A. 1995. Jonathan Edwards and the Catholic Vision of Salvation. University Park, PA: Pennsylvania State University Press.

Morris, W.S. 1955. The Young Jonathan Edwards. A Reconstruction. Chicago: PhD thesis, University of Chicago; 2005. The Jonathan Edwards Classic Studies Series, Eugene, OR: Wimf and Stock.

Muller, R.A. 2003. Post-Reformation Reformed Dogmatics. The Rise and Development of Reformed Orthodoxy, ca. 1520 to ca. 1725. Grand Rapids: Baker Academics, Vol. 1-4.

Noll, M.A., Bebbington, D.W. \& Rawlyk, G.A. (eds.), Evangelicalism: Comparative Studies of Popular Protestantism in North America, the British Isles, and Beyond 1700-1790. New York: Oxford University Press. [O'Brien S 1994. Eighteenth-Century Publishing Networks in the First Years of Transatlantic Evangelicalism].

Perkins, P. A Golden Chain. London 1592.

Ramus, P. Commentariorum De Religione Christiana. Frankfurt: A. Welchem, 1576.

Ridderbos, J. 1907. De Theologie van Jonathan Edwards. 's-Gravenhage: Johan A. Nederbragt.

Seccombe, J. Some occasional thoughts on the influence of the Spirit with seasonable cautions against mistakes and abuses. Boston: S. Kneeland and T. Green 1742.

Sprunger, K.L. 1972. The learned Doctor William Ames. Urbana: University of Illinois Press.

Stout, H.S. (ed.) [1957] 1992. The Works of Jonathan Edwards. vol. 1-26. New Haven, London: Yale University Press.

Turretin, F. Institutio theologiæ elencticæ in qua status controversiæ perspicue exponitur, præcipua orthodoxorum argumenta proponuntur \& vindicantur, \& fontes solutionum aperiuntur. Geneve: Samuelem de Tournes, 1680-1686. 